\title{
Agri-Food Export Competitiveness in European Union Countries
}

\section{ŠTEFAN BOJNEC ${ }^{1}$ and IMRE FERTŐ ${ }^{2,3}$}

\section{${ }^{1}$ University of Primorska, ${ }^{2}$ Corvinus University of Budapest, ${ }^{3}$ Institute of Economics, Centre for Economic and Regional Studies, Hungarian Academy of Sciences}

\begin{abstract}
This article investigates the competitiveness of agri-food exports of the European Union (EU27) countries on global markets, using the revealed comparative advantage (B) index over the 2000-2011 period. Panel unit root tests, mobility index and the Kaplan-Meier survival rates of the B index are used. The majority of agri-food products in the EU-27 countries show a comparative disadvantage on global markets. The B indices of the EU-27 countries tend to convergence. Most of the old EU-15 member states experienced a greater number of agri-food products having a longer duration of revealed comparative advantages than most of the new EU-12 member states have. Among the most successful member states in agri-food export competitiveness on global markets are the Netherlands, France and Spain.
\end{abstract}

Keywords: Agri-food export competitiveness; revealed comparative advantage; panel unit root tests, duration analysis; European Union.

JEL classifications: $F 14, C 23, Q 17$. 


\section{Introduction}

The European Union (EU) failed to achieve the objective of the Lisbon strategy to become the most competitive region in the world by 2010. The specific reasons for the failure of this optimistic objective might be different in each of the EU-27 countries and in different economic sectors.

This paper investigates the agri-food export competitiveness of the EU-27 countries on global markets. The increasing integration of agri-food products into global markets might strengthen exports towards comparative advantages (FAO, 2013; WTO, 2013). Therefore, determining whether expanding EU integration has led to an increase in the competitiveness of the EU agri-food sector with possible changes in export dynamics is a valuable research and policy issue.

This paper is motivated by the following three EU institutional policy developments and empirical facts. First, the EU Commission, in various documents, argues for the importance of increasing the competitiveness of the EU economies, including the agri-food sector. Some studies using different trade and trade competitiveness indicators, such as the Commission of the European Communities (2011), have asserted that a threat of decreasing competitiveness of the EU agri-food sector on world markets exists. The need to improve agri-food export competitiveness in global markets is an obvious objective.

Second, EU enlargement has become a challenging issue in terms of increasing agri-food competitiveness on global markets. One research and policy question is how the enlarged EU27 countries have been able to utilize the opportunities created by enlargement to increase agri-food competitiveness on global markets. The literature on productivity growth, changes in relative competitiveness between sub-sectors and countries, and efficiency in the agri-food sectors suggests stagnating or deteriorating competitiveness of EU countries (Latruffe, 2010). 
Finally, there is not a single study investigating the agri-food export competitiveness of the EU-27 countries before and after the EU enlargements. This paper aims to fill this gap in the literature.

Our research focuses on the question of how the EU-27 countries perform in agri-food exports in global markets in association with the EU enlargements. More specifically, this paper tests the following three main hypotheses. First, the agri-food export competitiveness in the EU-27 countries on the global markets differs according to individual countries. Second, the agri-food export competitiveness in the EU-27 countries on the global markets has increased. Third, the agri-food export specialization and the agri-food export specialization dynamics in the EU-27 countries on the global markets tend to converge.

The remaining part of this paper is structured in five sections. Section I provides a literature review on trade, agri-food trade competitiveness and trade duration, focusing on EU countries. Section II explains the methodology of the calculation of the revealed comparative advantage (B) index and the approaches used for panel unit root tests and for the duration analyses. Three different panel unit root tests with and without time trends are employed. In addition, the mobility indices and the Kaplan-Meier survival rates of agri-food B indices of the EU-27 countries are used. Section III describes the data used. Section IV presents the main research results and explains their meanings. Finally, Section V concludes with a summary of the findings of the paper.

\section{Literature Review}

Export competitiveness and its association with economic integration and economic growth were widely investigated by Balassa (1971, 1975 and 1988). His particular contribution is an investigation of the B index as an analysis of relative export shares of a country's product vis- 
à-vis the benchmark market (Balassa, 1965 and 1977). From the theoretical and methodological points of view, this was further developed by Vollrath (1991).

Mayes (1978) provided a critical analysis of the models and methods of the examination of the effects of economic integration on trade flows and their changes. International trade and economic integration allow for the more efficient usage of resources and expose domestic producers to larger, more competitive markets and specialization concurrent with a country's comparative advantage.

Over the previous two decades, the east-west integration within the EU in the context of the global economy and global economic principles has been one of the most salient research and policy issues (Zysman and Schwartz, 1998). At the same time, the objective of the EU internal policies has been to become one of the most competitive economies in the world (Howarth, 2007); however, this objective has not been achieved. Akman and Kassim (2010) have argued that one of the reasons for failures can be found in the unrealistically set objectives of the EU's competition policy.

The impact of the eastward EU enlargement on the region's competitiveness and on global markets has been analyzed by a few studies that provide evidence regarding various aspects of changes in agri-food trade and competitiveness patterns, trade specialization and trade dynamics between post-communist Central and Eastern European countries (CEECs) and the EU (Fertő and Hubbard, 2003; Török and Jámbor, 2013).

Crespo and Fontoura (2007) analyzed the integration of the CEECs into the EU market, focusing on structural change and convergence for trade in manufacturing goods. They found that the transformation of CEECs' export structures led to structural convergence towards preexisting EU members at inter- and intra-sectoral levels. 
Bojnec and Fertö (2008) investigated the level and composition of the agri-food trade patterns of the 12 new EU member states (EU-12). ${ }^{1}$ Agri-food trade has increased following EU enlargement, but trade specialization varies across the EU-12 and product groups. Variation in the mobility of trade specialization implies deterioration in the trade specialization pattern over time for the EU-12 member states in the enlarged single market.

Bojnec and Fertő (2012) confirmed gains in new EU member states from the eastward EU enlargement on agri-food export increases and the longer duration in the EU markets for exporting higher value-added, specialized, consumer-ready food and more competitive niche agri-food products.

Török and Jámbor (2013) found diversity in the EU-12's agri-food trade specialization, with deterioration and weakening stability following the convergence of the pattern of revealed comparative export advantage after accession.

In summary, the focus of the previous studies has been on agri-food trade performance and competitiveness between the new EU-12 member states and the old EU-15 member states, with problems arising from the competitiveness of the new EU-12 member states in processed and consumer-ready, higher value-added agri-food products. Thus far, there has been no study to examine the export performance of the EU-27 countries in agri-food products on the global markets before and after the previous two EU enlargements. In the absence of empirical analysis on the competitiveness of the EU agri-food exports on global markets, the challenging issues are determining in-depth empirical facts to measure the outcomes of the EU enlargements and competition policy on the export competitiveness of the agri-food sector. The performances compared in this paper are measured by the B indices and their dynamics and duration over time. The B indices of the EU-27 and the individual years in the 2000-2011 period capture both the effects of global policy changes with trade

\footnotetext{
${ }^{1}$ New EU-12 member states consists of two enlargements: on 1st May 2004 (New EU-10: Cyprus, Czech Republic, Estonia, Hungary, Latvia, Lithuania, Malta, Poland, Slovakia and Slovenia) and on 1st January 2007 (New EU-2: Bulgaria and Romania).
} 
liberalization and the internal EU policies and the EU enlargements. Global policy changes have strengthened the conception of global competitiveness (e.g. Hay, 2007). The internal EU policies and the EU enlargements have aimed to establish institutional settings (Daugbjerg and Swinbank, 2007), thereby reinforcing global competitiveness (Howarth, 2007; Akman and Kassim, 2010). This paper rectifies the missing empirical research and policy competitiveness issues in the theoretical and empirical literature in the case of the agri-food export competitiveness of the enlarged EU-27 countries in global markets.

\section{Methodology}

This paper employees the concept of 'revealed' comparative advantage introduced by Liesner (1958) and later redefined and popularized by Balassa (1965 and 1977). Therefore, it is known as the 'Balassa index' for empirically identifying a country's weak and strong export sectors. The Revealed Comparative Advantage (B) index has been defined (Balassa, 1965) as follows:

$$
\mathrm{B}=(\mathrm{Xij} / \mathrm{Xig}) /(\mathrm{Xwj} / \mathrm{Xwg})
$$

where $X$ represents exports, $i$ is a country, $j$ is a commodity, $g$ is a set of commodities, and $w$ is a set of countries that are used as the benchmark export markets for comparisons. $B$ is based on observed export patterns. In this paper, the B index is calculated at the World Customs Organization's Harmonized System (HS) at the six-digit level. It measures a country's exports of a commodity relative to its total exports and to the corresponding export performance of a set of countries, e.g. the world's agri-food exports. If B > 1, a country's agri-food comparative advantage on the world market is revealed. Despite some critiques of the B index as an export specialization index, such as the asymmetric value problem and problem with logarithmic transformation (De Benedictis and Tamberi, 2004) and the importance of the simultaneous 
consideration of the import side (Vollrath, 1991), it can provide useful evidence regarding the competitiveness of the EU-27 agri-food exports on global markets.

We focus on the stability of the B indices over time. At least two types of stability from one period to the next can be distinguished: (i) stability of the distribution of the indices; and (ii) stability of the value of the indices for particular product groups.

The first type of stability of the distribution of the $B$ indices portrays convergence/divergence in the revealed comparative advantage. The theoretical literature on growth and trade emphasizes that comparative advantage is dynamic and develops endogenously over time. In particular, one strand of the literature (Lucas, 1988; Young, 1991; Grossman and Helpman, 1991) has demonstrated that the growth rate of a country may be permanently reduced by a 'wrong' specialization. Another strand emphasizes the role of factor accumulation in determining the evolution of international trade (Findlay, 1970, 1995; Deardorff, 1974).

Time series investigation of the convergence hypothesis in economic literature often relies on unit root tests of the null hypothesis on the existence of the panel unit root in time series data; the alternative is that the times series are stationary. The rejection of the null hypothesis on the existence of the panel unit root is commonly interpreted as evidence that the time series are stationary and have converged to their equilibrium state, since any shock that causes deviations from equilibrium eventually disappears. The extension of these tests to the panel framework has significantly influenced the literature on measuring the convergence of economic variables. Over the previous decade, a number of panel unit root tests have been developed (Baltagi, 2008). Considering the well-known low-power properties of unit root tests for checking convergences or divergence in the B indices, three panel unit root tests with and without trend specifications, respectively, as deterministic components are used: the Im et al. (2003) method (assuming individual unit root processes), ADF-Fisher Chi-square, and PP- 
Fisher Chi-square (Maddala and Wu, 1999; Choi, 2001). In addition, the lag length of explanatory variables has been chosen according to the Modified Akaike Information Criterion (MAIC) proposed by $\mathrm{Ng}$ and Perron (2001).

The second type of stability of the value of the B indices for particular product groups is investigated in two steps. First, the Markov transition probability matrices are employed to identify the persistence and mobility of the $\mathrm{B}$ indices. Products are classified into two categories: products with revealed comparative disadvantage $(\mathrm{B}<1)$ and products with revealed comparative advantage $(B>1)$. Second, the degree of mobility in patterns of the revealed comparative advantage can be summarized using an index of mobility. This formally evaluates the degree of mobility throughout the entire distribution of B indices and facilitates direct cross-country comparisons. The mobility index, $\mathbf{M}_{1}$, following Shorrocks (1978), evaluates the trace $(t r)$ of the Markov transition probability matrix. This $\mathrm{M}_{1}$ index thus directly captures the relative magnitude of diagonal and off-diagonal terms, and can be shown to equal the inverse of the harmonic mean of the expected duration of remaining in a given cell:

$$
\mathrm{M}_{1}=\frac{\mathrm{K}-\operatorname{tr}(\mathrm{P})}{\mathrm{K}-1}
$$

where $K$ is the number of cells, and $P$ is the Markov transition probability matrix. A higher value of $\mathrm{M}_{1}$ index indicates greater mobility (the upper limit is two in our case), with a value of zero indicating perfect immobility.

Duration analysis of the revealed comparative advantage $(B>1)$ in EU-27 countries is estimated by the survival function, $S(t)$, using the nonparametric Kaplan-Meier product limit estimator (Cleves et al., 2004). It is assumed that a sample contains $n$ independent observations denoted $\left(t_{i} ; c_{i}\right)$, where $i=1,2, \ldots, \mathrm{n}, t_{i}$ is the survival time, and $c_{i}$ is the censoring indicator variable $C$, which takes a value of 1 if failure occurred, and 0 otherwise of observation $i$. It is assumed that there are $\mathrm{m}<\mathrm{n}$ recorded times of failure. The rank-ordered 
survival times are denoted as $t(1)<t(2)<\ldots<t(m)$, while $n_{j}$ denotes the number of subjects at risk of failing at $t(j)$, and $d_{j}$ denotes the number of observed failures. The Kaplan-Meier estimator of the survival function is then:

$$
\hat{S}(t)=\prod_{t(i)<t} \frac{n_{j}-d_{j}}{n_{j}},
$$

with the convention that $\hat{S}(t)=1$ if $\mathrm{t}<\mathrm{t}\left({ }_{1}\right)$. Given that many observations are censored, it is then noted that the Kaplan-Meier estimator is robust to censoring and uses information from both censored and non-censored observations.

\section{Data}

The United Nations International Trade Statistics UN Comtrade database, specifically with the six-digit harmonized commodity description and coding systems (HS6-1996), is used for agri-food exports of the EU-27 countries to world markets in the years 2000-2011. The annual sample of agri-food trade as defined by the World Trade Organization contains 789 product groups at the HS six-digit level. The UN Comtrade database with the World Integrated Trade Solution (WITS) software developed by the World Bank, in close collaboration and consultation with various international organizations, including the United Nations Conference on Trade and Development (UNCTAD), the International Trade Center (ITC), the United Nations Statistical Division (UNSD) and the WTO is used. The value of trade is expressed in US dollars.

Table 1 presents agri-food exports, imports and trade balance (exports - imports) of the EU-27 countries in 2000 and 2011. The EU-27 countries agri-food exports are of similar sizes as agri-food imports. While the EU-27 countries experienced rather balanced agri-food trade, greater differences are seen between the countries. In addition to the size of the country, the level of agro-food exports reflects the competitiveness of agri-food sector in global markets. 
The main agri-food exporters are the Netherlands, France, Denmark, Spain, Ireland, and Belgium. In addition to these old EU-15 countries, from the group of NMS-12 Hungary, most recently Poland, and to a lesser extent Bulgaria are also important net agri-food exporters. The main net agri-food importers are Germany, the United Kingdom, Italy, Sweden, and Portugal.

Table 1: Agri-food exports, imports and trade balance in 2000 and 2011 (in million US dollars)

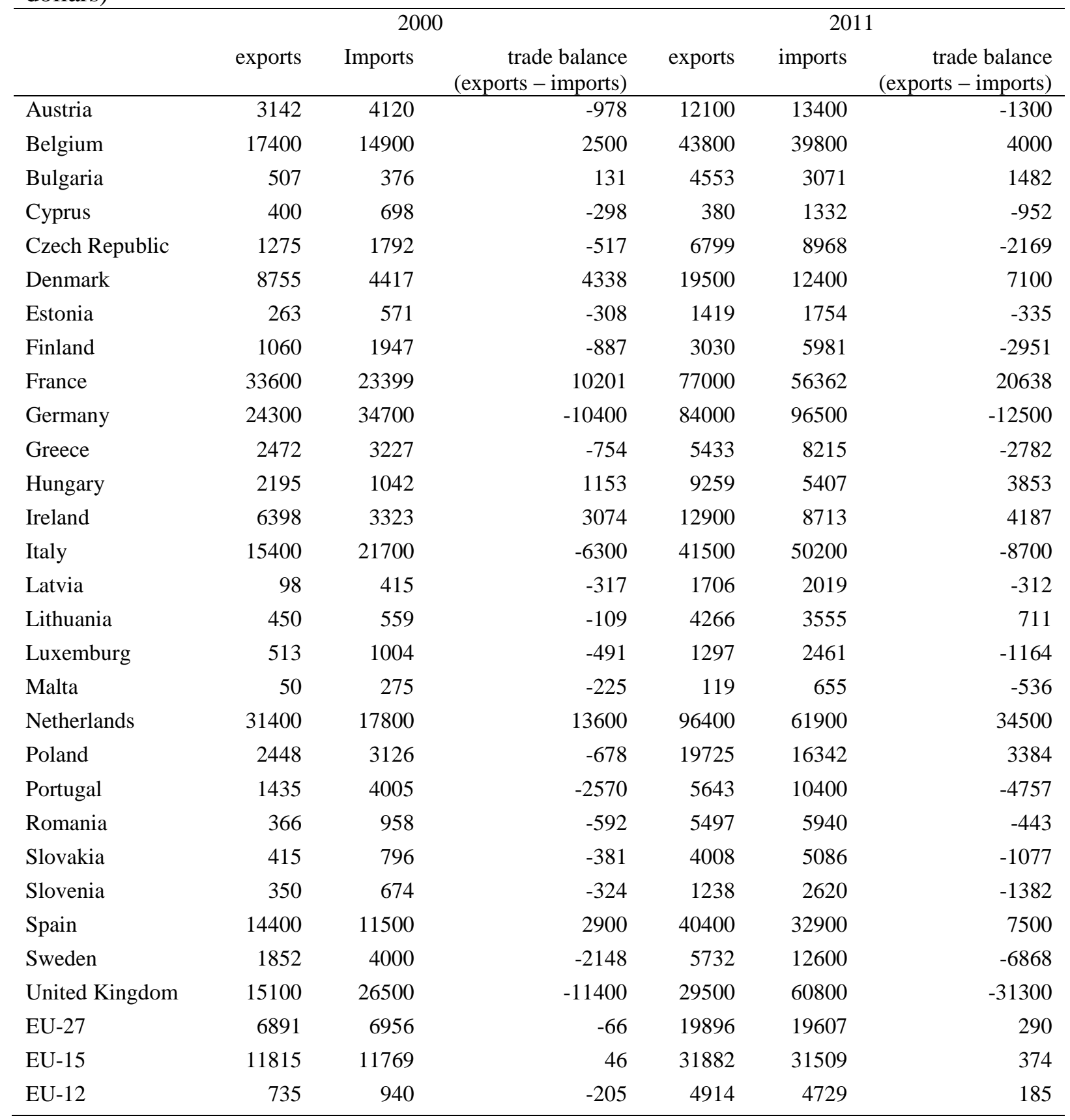

Note: Data for EU-27, EU-15 and EU-12 are arithmetic mean values.

Source: Own calculations based on Comtrade database with WITS (World Trade Integration Solution) software 


\section{Results}

\section{Changes in Revealed Comparative Advantage (B) Indices}

The enlarged EU-27 countries have performed differently according to the B indices. Table 2 presents the results for the first (2000) and the final (2011) analyzed years. However, the B indices have also been calculated for all other years in the 2000-2011 period to investigate their patterns in development, the effects of the EU enlargements, and the survival of the $\mathrm{B}>1$ indices across all the years in the considered period.

In general, the EU-27 have been competitive in agri-food exports to global markets with an increasing percentage of agri-food products with revealed comparative advantage $(B>1)$. The B indices for the EU-12 countries are higher than for the EU-15 countries, but dynamic improvements are clearly visible only for the EU-15 countries, while stagnation or deterioration are seen for the EU-12 countries. ${ }^{2}$ The EU-27 market is a significant market outlet for its members. Therefore, the net result of the EU enlargements between the EU-15 and the EU-12 countries is rather asymmetric.

The distribution of the mean and median values of the B indices and for the percentage of agri-food products with $\mathrm{B}>1$ of the EU-27 countries on world markets indicates four main groups of EU-27 countries.

First, the group of the four EU-15 countries with the highest B value: Belgium, France, the Netherlands, and Spain. They experienced mean values for the $\mathrm{B}>1$, the highest median values for the $\mathrm{B}$ value, and increasing or stable percentages of agri-food products with $\mathrm{B}>1$. Moreover, the distribution of the median values of the B indices for the EU-27 countries' agri-food exports to the world markets clearly indicates that (except for the Netherlands) there

\footnotetext{
${ }^{2}$ A Chow test has been performed in order to confirm the presence of structural break. The Chow tests confirmed the presence of a structural break in the time series of B indices before and after the 2004 and 2007 EU enlargements for Poland, Slovakia, Romania, and to a lesser extent for Lithuania. These countries are new EU member states. Among the EU-12 countries, the Chow tests clearly rejected a structural break for Bulgaria, Cyprus, the Czech Republic, Estonia, Hungary, Latvia, Malta, and Slovenia.
} 
is no other EU-27 country with a B median value close to or greater than 1 . There is only a relatively small group of EU-27 countries with B median values greater than 0.5: Belgium, France, and Spain.

Second is a larger group of EU-15 countries (Denmark, Greece, Ireland, Italy, Luxembourg, and Portugal) and of EU-12 countries (Bulgaria, Cyprus, Estonia, Hungary, Latvia, Lithuania, and Poland) that experienced competitive agri-food exports to world markets (B>1) but median B values. It is noteworthy that the B index for Luxembourg is close to 1 . The dynamics for the percentage of the products with the $B>1$ of this group of countries are mixed. Similar as for Greece and to a lesser extent for Denmark among the EU-15 countries, some deterioration is seen for Cyprus, Hungary and Poland among the EU-12 countries.

Third, Malta and Finland are exceptional cases. Malta experienced a shift of the mean from $\mathrm{B}<1$ to $\mathrm{B}>1$, but with a reduced median value for the $\mathrm{B}$ index and a reduced percentage of agri-food products with $\mathrm{B}>1$. Among the EU-15 countries, Finland experienced a shift from $\mathrm{B}<1$ to $\mathrm{B}>1$ with a slight increase in the median $\mathrm{B}$ value and in the percentage of agri-food products with $\mathrm{B}>1$. Finally, there is the fourth group of the EU-15 countries (Austria, Germany, Sweden, and the United Kingdom) and the EU-12 countries (Slovakia and Slovenia as well as the Czech Republic and Romania) that experienced the mean value of $B<1$. The percentage of agri-food products with $\mathrm{B}>1$ increased for the former countries and declined for the latter. In addition, the deterioration with a shift from $\mathrm{B}>1$ to $\mathrm{B}<1$ is seen for the Czech Republic and Romania in the group of the EU-12 countries, with a reduced percentage of agri-food products with $\mathrm{B}>1$.

To summarize, the results for the $\mathrm{B}$ indices imply that most of the EU-27 countries experienced a mean value of $\mathrm{B}>1$ for agri-food exports on world markets. However, in most of these countries the median values are less than 0.5 , suggesting the majority of agri-food 
products exhibit revealed comparative disadvantages $(\mathrm{B}<1)$ on global markets. The difference between mean and median values for some EU-27 countries suggests the heterogeneity in the agri-food export competitiveness by products or sub-sectors.

Table 2: Changes in B Indices between 2000 and 2011

\begin{tabular}{|c|c|c|c|c|c|c|c|c|c|}
\hline & \multicolumn{3}{|c|}{ Mean } & \multicolumn{3}{|c|}{ Median } & \multicolumn{3}{|c|}{ Share B>1 (per cent) } \\
\hline & 2000 & 2011 & $\begin{array}{l}\text { Average } \\
2000-11\end{array}$ & 2000 & 2011 & $\begin{array}{l}\text { Average } \\
2000-11\end{array}$ & 2000 & 2011 & $\begin{array}{l}\text { Average } \\
2000-11\end{array}$ \\
\hline Austria & 0.76 & 0.91 & 0.79 & 0.17 & 0.24 & 0.20 & 18.0 & 22.8 & 20.3 \\
\hline Belgium & 1.57 & 1.50 & 1.46 & 0.58 & 0.59 & 0.56 & 38.2 & 38.9 & 36.8 \\
\hline Bulgaria & 3.21 & 3.15 & 3.46 & 0.13 & 0.32 & 0.18 & 27.8 & 31.3 & 28.4 \\
\hline Cyprus & 14.02 & 6.45 & 8.59 & 0.30 & 0.38 & 0.40 & 36.7 & 34.4 & 36.3 \\
\hline Czech Republic & 1.15 & 0.70 & 0.78 & 0.15 & 0.16 & 0.14 & 21.4 & 16.0 & 16.0 \\
\hline Denmark & 2.20 & 2.17 & 2.09 & 0.29 & 0.27 & 0.25 & 31.3 & 30.9 & 29.5 \\
\hline Estonia & 1.43 & 1.13 & 1.26 & 0.12 & 0.16 & 0.12 & 21.7 & 23.2 & 22.6 \\
\hline Finland & 0.70 & 1.58 & 0.94 & 0.02 & 0.04 & 0.02 & 8.7 & 12.3 & 9.7 \\
\hline France & 1.56 & 1.72 & 1.62 & 0.77 & 0.75 & 0.74 & 43.7 & 43.5 & 43.3 \\
\hline Germany & 0.67 & 0.75 & 0.69 & 0.31 & 0.42 & 0.36 & 19.8 & 27.9 & 23.0 \\
\hline Greece & 4.64 & 3.08 & 3.95 & 0.27 & 0.27 & 0.33 & 32.0 & 28.4 & 31.6 \\
\hline Hungary & 3.51 & 1.72 & 2.39 & 0.63 & 0.23 & 0.38 & 39.9 & 29.5 & 33.2 \\
\hline Ireland & 1.08 & 1.52 & 1.24 & 0.09 & 0.08 & 0.08 & 21.7 & 22.9 & 21.6 \\
\hline Italy & 1.09 & 1.35 & 1.16 & 0.28 & 0.39 & 0.32 & 25.9 & 30.2 & 27.5 \\
\hline Latvia & 1.66 & 1.96 & 1.86 & 0.07 & 0.41 & 0.20 & 20.0 & 34.6 & 26.4 \\
\hline Lithuania & 2.97 & 2.28 & 2.17 & 0.19 & 0.49 & 0.37 & 25.9 & 38.5 & 31.7 \\
\hline Luxemburg & 1.07 & 1.05 & 0.99 & 0.04 & 0.08 & 0.05 & 13.2 & 13.8 & 12.5 \\
\hline Malta & 0.94 & 1.74 & 1.63 & 0.07 & 0.03 & 0.04 & 11.4 & 9.2 & 11.7 \\
\hline Netherlands & 1.97 & 2.35 & 2.00 & 0.90 & 1.24 & 0.97 & 48.2 & 55.7 & 49.4 \\
\hline Poland & 3.50 & 1.48 & 1.95 & 0.72 & 0.41 & 0.46 & 42.2 & 33.9 & 36.2 \\
\hline Portugal & 1.03 & 1.39 & 1.13 & 0.11 & 0.32 & 0.18 & 17.3 & 28.2 & 21.9 \\
\hline Romania & 1.65 & 0.90 & 0.98 & 0.07 & 0.09 & 0.06 & 19.0 & 13.9 & 14.1 \\
\hline Slovakia & 0.82 & 0.92 & 0.94 & 0.14 & 0.13 & 0.18 & 19.3 & 18.2 & 19.7 \\
\hline Slovenia & 0.80 & 0.66 & 0.71 & 0.07 & 0.08 & 0.07 & 16.5 & 12.0 & 12.8 \\
\hline Spain & 2.21 & 2.30 & 2.24 & 0.64 & 0.75 & 0.70 & 39.7 & 44.8 & 42.4 \\
\hline Sweden & 0.42 & 0.51 & 0.49 & 0.05 & 0.09 & 0.08 & 7.9 & 11.9 & 10.5 \\
\hline United Kingdom & 0.74 & 1.00 & 0.82 & 0.25 & 0.27 & 0.25 & 18.3 & 22.8 & 20.2 \\
\hline EU-27 & 2.13 & 1.71 & 1.79 & 0.27 & 0.32 & 0.29 & 25.0 & 27.0 & 25.5 \\
\hline EU-15 & 1.45 & 1.55 & 1.44 & 0.32 & 0.39 & 0.34 & 26.0 & 29.0 & 26.7 \\
\hline EU-12 & 2.97 & 1.92 & 2.21 & 0.22 & 0.24 & 0.21 & 25.0 & 24.6 & 24.1 \\
\hline
\end{tabular}

Note: Data for EU-27, EU-15 and EU-12 are arithmetic mean values. 2000-11 represents the 2000-2011 period.

Source: Own calculations based on Comtrade database with WITS (World Trade Integration Solution) software

\section{Dynamics of the B Indices}

To investigate convergence vis-à-vis divergence in the dynamics of the B indices, panel unit root tests with and without trend specifications as a deterministic component are used (Table 3). The empirical results of the three different panel unit root tests (except for Latvia and to a 
lesser extent for Italy with a specification as a deterministic component) clearly reject the existence of the panel unit root hypothesis. This implies that the B indices of the EU-27 countries are stationary, confirming the hypothesis of convergence. In other words, we find the convergence in the dynamics of the B indices in the EU-27 countries. This implies that similar characteristics tend toward a common distribution of the $\mathrm{B}$ indices, with falling (rising) in the dynamics of the B indices in the EU-27 countries of initially high (low) B indices in agri-food products.

Table 3: Panel Unit Root Tests for the B Indices, 2000-2011 (p-values)

\begin{tabular}{lcccccc}
\hline & \multicolumn{3}{c}{ without time-trend } & \multicolumn{3}{c}{ with time-trend } \\
& IPS & ADF & PP & IPS & ADF & PP \\
\hline France & 0.0000 & 0.0000 & 0.0000 & 0.0085 & 0.0000 & 0.0000 \\
Germany & 0.0000 & 0.0000 & 0.0000 & 0.0004 & 0.0000 & 0.0000 \\
Italy & 0.0000 & 0.0000 & 0.0000 & 0.0913 & 0.0004 & 0.0000 \\
Latvia & 0.0000 & 0.0000 & 0.0000 & 0.2505 & 0.0810 & 0.0000 \\
\hline
\end{tabular}

Note: IPS (Im, Pesaran and Shin W-stat), ADF (ADF-Fisher Chi-square), PP (PP-Fisher Chisquare). Table presents only countries with $\mathrm{p}$-values different from zero at the four-digit level. Source: Own calculations based on Comtrade database with WITS (World Trade Integration Solution) software

\section{Mobility of the Revealed Comparative Advantage (B) Indices}

The degree of mobility in patterns throughout the entire distribution of the $\mathrm{B}$ indices of the EU-27 countries is estimated using the mobility index, $\mathrm{M}_{1}$, based on the Markov transition probability matrices using a one-year lag. The Markov matrices for each of the EU-27 country show (not presented here) on the presence of very low probability (below 10 per cent) that agri-food products with a revealed comparative disadvantage $(B<1)$ might shift to a revealed comparative advantage $(\mathrm{B}>1)$. Similarly, there are low the chances that those products with a B $>1$ may move backward by a switch to a $\mathrm{B}<1$. The M1 mobility indices are calculated for EU-27 cross-country comparison. The empirical results in Table 4 indicate relatively low 
mobility in the B indices at the product level for the EU-27 countries. Except for Greece, the M1 indices of the EU-15 countries are less than 0.2, indicating rather high stability in patterns of the B indices for agri-food products. Except for Hungary, Poland and Slovenia, the M1 indices are a slightly higher than 0.2 for the EU-12 countries, but still indicate a low degree of mobility in patterns throughout the entire distribution of the B indices for agri-food products.

The disaggregated analysis confirms the low degree of mobility in the B indices for grains, fruit and vegetables, dairy, and meat products, but with some differences between the EU-27 countries. However, the mean values of the M1 indices in the EU-27 countries are relatively low: 0.29 for dairy products, 0.30 for fruit and vegetables, and 0.33 for grains and meat products. 
Table 4: Mobility of B Indices, 2000-2011

\begin{tabular}{lr}
\hline & M1 \\
\hline Austria & 0.1502 \\
Belgium & 0.1276 \\
Bulgaria & 0.2049 \\
Cyprus & 0.2880 \\
Czech Republic & 0.2155 \\
Denmark & 0.1232 \\
Estonia & 0.2269 \\
Finland & 0.0987 \\
France & 0.1138 \\
Germany & 0.1099 \\
Greece & 0.2216 \\
Hungary & 0.1684 \\
Ireland & 0.1820 \\
Italy & 0.1201 \\
Latvia & 0.2396 \\
Lithuania & 0.2197 \\
Luxemburg & 0.1617 \\
Malta & 0.2769 \\
Netherlands & 0.1607 \\
Poland & 0.1763 \\
Portugal & 0.1798 \\
Romania & 0.2297 \\
Slovakia & 0.2403 \\
Slovenia & 0.1909 \\
Spain & 0.1396 \\
Sweden & 0.1682 \\
Enited Kingdom & 0.1517 \\
EU-15 & 0.1810 \\
EU-12 & 0.1473 \\
\hline Note M1 & 0.2231 \\
\hline
\end{tabular}

Note: M1 can take values: $0<M 1<2$. Data for EU-27, EU-15 and EU-12 are arithmetic mean values.

Source: Own calculations based on Comtrade database with WITS (World Trade Integration Solution) software

\section{Duration of the Revealed Comparative Advantages $(B>1)$}

The duration of the $\mathrm{B}$ indices is investigated in two steps: first, the duration of $\mathrm{B}>1$, and second, the description of the periods of time (or 'spells') of $\mathrm{B}>1$. The former indicates for how many years $\mathrm{B}>1$ at agri-food product levels, ranging from 1 to 12 years. The latter 
indicates whether $\mathrm{B}>1$ is a continuous process during the analyzed periods. A spell is a way to distinguish a continuous period with $\mathrm{B}>1$ from the total number of the analyzed years (continuous or not) with $\mathrm{B}>1$.

Figure 1: Histogram of Duration of the B>1, 2000-2011 (in percentage of the number of agrifood products at the HS-6 level)

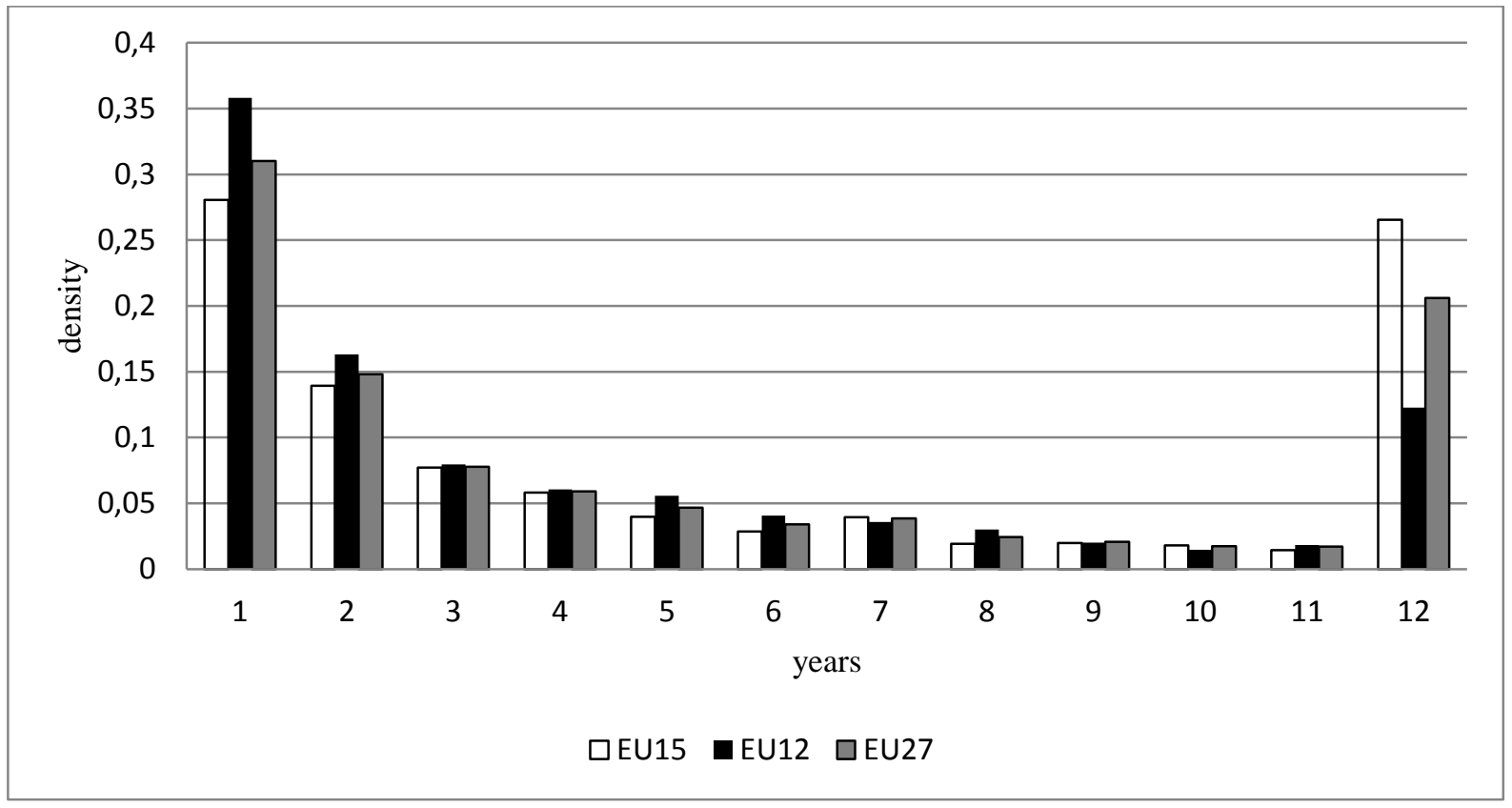

Note: The exit rates from being with the continued survival in export competitiveness are indicated up to 11 years, and for the $12^{\text {th }}$ year the continued survival rate in export competitiveness at the HS-6 agri-food product level. Data for EU-27, EU-15 and EU-12 are arithmetic mean values.

Figure 1 clearly indicates that the distribution of the duration density of the number of agrifood products with $\mathrm{B}>1$ for the EU-12 countries is concentrated on the left-hand side, indicating fewer years continuously being at $\mathrm{B}>1$, while the EU-15 is (except for years 8 and 11) concentrated on the right-hand side, indicating more years being continuously at $B>1$. The results imply greater numbers of agri-food products with longer durations of export competitiveness for the EU-15 countries than for the new EU-12 countries. 
Table 5 presents the results of the duration analysis of the $\mathrm{B}>1$ indices in the case of the number of agri-food products for each of the EU-27 countries. The largest number of agrifood products with $\mathrm{B}>1$ over the 12-year period, and with the highest mean years of the $\mathrm{B}>1$ duration (equal or greater than 6), are seen for the following EU-15 countries: Belgium, Denmark, France, Italy, the Netherlands, and Spain. Over the 12-year period, the number of agri-food products with $\mathrm{B}>1$ duration is the largest for the Netherlands (200), while the mean and median values of $\mathrm{B}>1$ duration are the highest for France (6.9 and 7 years, respectively). Except for Hungary and Poland, the corresponding numbers are much lower among the EU12 countries, indicating that they have experienced a smaller number of agri-food products with $\mathrm{B}>1$ and a shorter period of their $\mathrm{B}>1$ duration.

Table 5: Duration of the B>1 by Years, 2000-2011

\begin{tabular}{|c|c|c|c|c|c|c|c|c|c|c|c|c|c|c|}
\hline & 1 year & 2 year & 3 year & 4 year & 5 year & 6 year & 7 year & 8 year & 9 year & 10 year & 11 year & 12 year & mean & median \\
\hline Austria & 94 & 42 & 26 & 16 & 9 & 9 & 13 & 12 & 5 & 5 & 9 & 55 & 4.9 & 3 \\
\hline Belgium & 102 & 66 & 40 & 24 & 15 & 12 & 25 & 5 & 10 & 10 & 4 & 145 & 6.1 & 4 \\
\hline Bulgaria & 139 & 70 & 31 & 31 & 19 & 14 & 10 & 3 & 8 & 6 & 9 & 63 & 4.4 & 2 \\
\hline Cyprus & 143 & 38 & 21 & 21 & 15 & 14 & 14 & 5 & 5 & 5 & 3 & 30 & 3.7 & 2 \\
\hline Czech Republic & 110 & 60 & 17 & 10 & 17 & 7 & 11 & 12 & 4 & 4 & 1 & 34 & 3.9 & 2 \\
\hline Denmark & 91 & 55 & 20 & 17 & 12 & 12 & 12 & 6 & 11 & 10 & 6 & 104 & 5.9 & 4 \\
\hline Estonia & 116 & 45 & 28 & 25 & 23 & 10 & 14 & 5 & 3 & 3 & 9 & 32 & 4.0 & 2 \\
\hline Finland & 26 & 16 & 5 & 7 & 7 & 3 & 5 & 1 & 3 & 2 & 4 & 23 & 5.5 & 4 \\
\hline France & 98 & 42 & 36 & 18 & 20 & 12 & 27 & 10 & 11 & 8 & 7 & 183 & 6.9 & 7 \\
\hline Germany & 70 & 41 & 28 & 19 & 11 & 8 & 18 & 9 & 3 & 10 & 6 & 77 & 5.8 & 4 \\
\hline Greece & 166 & 67 & 39 & 32 & 22 & 17 & 11 & 4 & 3 & 5 & 6 & 89 & 4.5 & 2 \\
\hline Hungary & 87 & 57 & 34 & 23 & 25 & 15 & 15 & 8 & 5 & 7 & 6 & 65 & 5.0 & 3 \\
\hline Ireland & 105 & 45 & 23 & 17 & 12 & 11 & 8 & 6 & 8 & 3 & 3 & 51 & 4.5 & 2 \\
\hline Italy & 94 & 56 & 23 & 23 & 8 & 5 & 13 & 7 & 7 & 4 & 5 & 112 & 5.8 & 4 \\
\hline Latvia & 159 & 56 & 38 & 20 & 20 & 22 & 13 & 16 & 10 & 5 & 9 & 29 & 3.8 & 2 \\
\hline Lithuania & 131 & 85 & 27 & 25 & 31 & 40 & 12 & 16 & 15 & 5 & 11 & 42 & 4.3 & 3 \\
\hline Luxemburg & 69 & 22 & 13 & 12 & 4 & 3 & 9 & 2 & 1 & 0 & 3 & 33 & 4.4 & 2 \\
\hline Malta & 42 & 7 & 6 & 6 & 4 & 2 & 1 & 1 & 0 & 1 & 1 & 4 & 2.9 & 1 \\
\hline Netherlands & 160 & 79 & 42 & 30 & 22 & 18 & 19 & 9 & 10 & 14 & 7 & 200 & 6.1 & 4 \\
\hline Poland & 122 & 60 & 26 & 22 & 16 & 9 & 28 & 21 & 13 & 5 & 8 & 86 & 5.3 & 3.5 \\
\hline Portugal & 120 & 42 & 32 & 27 & 17 & 10 & 10 & 6 & 6 & 6 & 4 & 52 & 4.4 & 3 \\
\hline Romania & 86 & 43 & 19 & 16 & 10 & 4 & 6 & 4 & 4 & 4 & 5 & 16 & 3.5 & 2 \\
\hline Slovakia & 112 & 49 & 29 & 16 & 18 & 5 & 8 & 12 & 4 & 7 & 3 & 25 & 3.7 & 2 \\
\hline Slovenia & 70 & 30 & 17 & 8 & 7 & 8 & 0 & 8 & 3 & 2 & 3 & 26 & 4.1 & 2 \\
\hline Spain & 117 & 75 & 33 & 33 & 17 & 10 & 17 & 10 & 19 & 9 & 8 & 167 & 6.2 & 4 \\
\hline Sweden & 56 & 26 & 18 & 9 & 9 & 6 & 8 & 4 & 1 & 2 & 3 & 25 & 4.4 & 3 \\
\hline United Kingdom & 91 & 51 & 23 & 18 & 22 & 12 & 10 & 9 & 5 & 5 & 0 & 65 & 4.9 & 3 \\
\hline
\end{tabular}

Note: The number of the HS-6 agri-food products that survived a certain number of years.

Source: Own calculations based on Comtrade database with WITS (World Trade Integration Solution) software

In addition to the number of years with $\mathrm{B}>1$, we turn to investigate the number of spells with $B>1$, focusing on the difference between single spells and multiple spells; the latter means that $\mathrm{B}>1$ may reoccur as multiple spells. A country may have $\mathrm{B}>1$ in a specific 
product, and may switch between ins and outs (Besedeš and Prusa, 2006). In our sample, the maximum length of a spell for a given country's product with continuous B $>1$ is 12 years, whilst the maximum number of spells due to switches year-to-year from $B>1$ to $B<1$ is six.

Figure 2 presents the distribution density of the number spells with $B>1$ for agri-food products. Around three quarters of the spells with $\mathrm{B}>1$ indices present a single spell continuously with B>1. This result holds both for the EU-15 and EU-12 countries.

Figure 2: Histogram of the Number of Spells with the $\mathrm{B}>1$

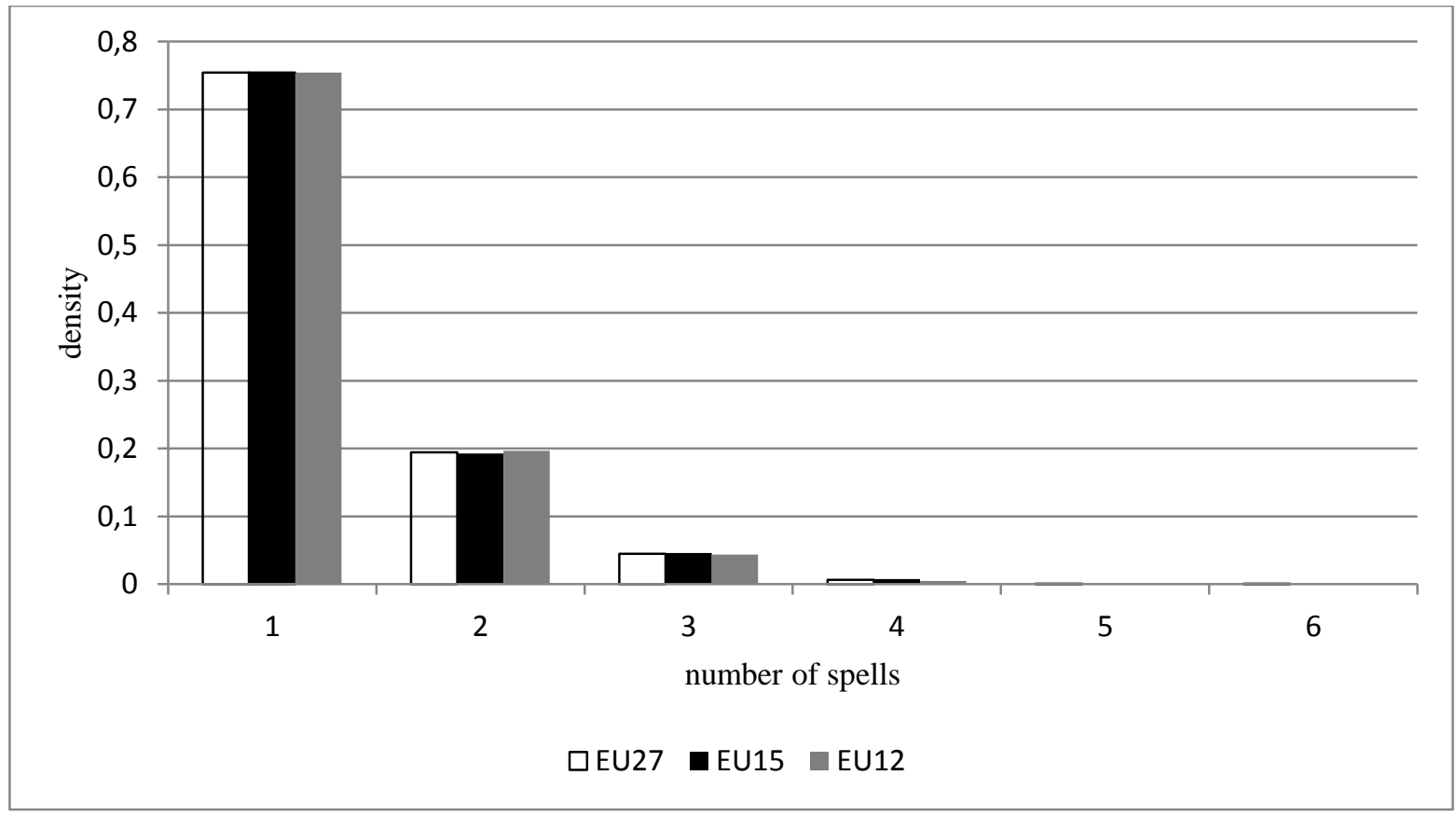

Note: The percentage of the number of the HS-6 agri-food products that survived a certain number of years 2000-2011. Data for EU-27, EU-15 and EU-12 are arithmetic mean values.

The disaggregated analysis confirms the high share of single spells of the $\mathrm{B}>1$ for different agri-food products, but with differences across products within countries. For example, the proportion of single spells in the total number of spells in the Netherlands is 84 per cent for dairy products, 73 per cent for fruit and vegetables, 72 per cent for grains, and 74 per cent for meat products. 


\section{Survival of the Revealed Comparative Advantages $(B>1)$}

The duration of the mean values of the $\mathrm{B}>1$ indices for agri-food exports for the EU-27 countries on the global market is tested by examining nonparametric Kaplan-Meier estimates of a survival function over the 12-year period. The mean values for more competitive EU-27 agri-food exporters are expected to be of longer duration. The Kaplan-Meier survival rates for the mean values of the $\mathrm{B}>1$ indices for each of the EU-27 countries have declined over time (Table 7). The duration of the mean values differs between the EU-27 countries and can be divided into three groups. First, the highest survival rates are found for France, the Netherlands, and Spain, each of which is an old EU-15 member state. Their higher survival rates over time imply their relatively higher revealed comparative advantages with higher survival rates. For France, this is for grains, meats, and dairy products, whilst for the Netherlands and Spain it is for fruit and vegetables, meats, and dairy products. Second, the modest Kaplan-Meier survival rates between 5 and 10 per cent over the 12-year period are found for some other EU-15 countries (Belgium, Denmark, Greece, and Italy) and some EU12 countries (Bulgaria, Cyprus, Hungary, Latvia, Lithuania, and Poland). For example, Belgium, Denmark and Poland experienced relatively higher survival rates for meats and dairy products, Greece and Italy for fruit and vegetables, Bulgaria for grains, Cyprus for meats, Hungary for grains and meats, Latvia for dairy products, and Lithuania for grains, fruit and vegetables, and dairy products. Finally, the Kaplan-Meier survival rates are relatively low (less than 5 per cent after 12 years) for more than half of the EU-15 countries (Austria, Finland, Germany, Ireland, Luxembourg, Portugal, Sweden, and the United Kingdom) and half of the EU-12 countries (the Czech Republic, Estonia, Malta, Romania, Slovakia, and Slovenia). Except for Ireland for meats and dairy products, and Germany, Estonia, Luxembourg, and Finland for dairy products, the results for this group of the EU-27 countries imply that the duration of their agri-food exports is shorter. This suggests potential limitations 
to the agri-food sector's natural agricultural factor endowments or their structural export ability and viability to competitively maintain their agri-food exports on global markets on a long-term basis.

Table 6: Kaplan-Meier Survival Rates for the Mean Values of the B>1 Indices (probability of continues survival of a certain year)

\begin{tabular}{|c|c|c|c|c|c|c|c|}
\hline & 1 year & 2 year & 3 year & 4 year & 5 year & 6 year & 12 year \\
\hline Austria & 0.9301 & 0.8571 & 0.7884 & 0.7160 & 0.6425 & 0.5684 & 0.0347 \\
\hline Belgium & 0.9458 & 0.8876 & 0.8287 & 0.7670 & 0.7026 & 0.6360 & 0.0895 \\
\hline Bulgaria & 0.9382 & 0.8726 & 0.8089 & 0.7450 & 0.6753 & 0.6069 & 0.0610 \\
\hline Cyprus & 0.9450 & 0.8910 & 0.8317 & 0.7700 & 0.7005 & 0.6348 & 0.0729 \\
\hline Czech Republic & 0.9343 & 0.8651 & 0.7939 & 0.7211 & 0.6444 & 0.5667 & 0.0202 \\
\hline Denmark & 0.9440 & 0.8841 & 0.8194 & 0.7544 & 0.6862 & 0.6142 & 0.0583 \\
\hline Estonia & 0.9325 & 0.8624 & 0.7906 & 0.7202 & 0.6473 & 0.5771 & 0.0382 \\
\hline Finland & 0.9177 & 0.8350 & 0.7558 & 0.6762 & 0.5935 & 0.5135 & 0.0130 \\
\hline France & 0.9509 & 0.8980 & 0.8455 & 0.7907 & 0.7326 & 0.6703 & 0.1167 \\
\hline Germany & 0.9300 & 0.8593 & 0.7904 & 0.7179 & 0.6438 & 0.5707 & 0.0453 \\
\hline Greece & 0.9445 & 0.8861 & 0.8268 & 0.7673 & 0.7050 & 0.6356 & 0.0589 \\
\hline Hungary & 0.9551 & 0.9079 & 0.8529 & 0.8010 & 0.7247 & 0.6466 & 0.0674 \\
\hline Ireland & 0.9350 & 0.8665 & 0.7961 & 0.7251 & 0.6562 & 0.5830 & 0.0353 \\
\hline Italy & 0.9355 & 0.8701 & 0.8042 & 0.7364 & 0.6668 & 0.5948 & 0.0551 \\
\hline Latvia & 0.9411 & 0.8842 & 0.8239 & 0.7585 & 0.6839 & 0.6111 & 0.0680 \\
\hline Lithuania & 0.9412 & 0.8846 & 0.8229 & 0.7604 & 0.6897 & 0.6157 & 0.0809 \\
\hline Luxemburg & 0.9306 & 0.8597 & 0.7848 & 0.7081 & 0.6299 & 0.5509 & 0.0168 \\
\hline Malta & 0.9199 & 0.8058 & 0.7220 & 0.6456 & 0.5919 & 0.5374 & 0.0092 \\
\hline Netherlands & 0.9557 & 0.9075 & 0.8598 & 0.8104 & 0.7547 & 0.6960 & 0.1765 \\
\hline Poland & 0.9665 & 0.9327 & 0.8954 & 0.8569 & 0.7787 & 0.7058 & 0.0819 \\
\hline Portugal & 0.9320 & 0.8639 & 0.7930 & 0.7223 & 0.6480 & 0.5735 & 0.0471 \\
\hline Romania & 0.9463 & 0.8908 & 0.8319 & 0.7576 & 0.6818 & 0.6032 & 0.0201 \\
\hline Slovakia & 0.9277 & 0.8539 & 0.7748 & 0.6947 & 0.6104 & 0.5548 & 0.0289 \\
\hline Slovenia & 0.9332 & 0.8668 & 0.7961 & 0.7247 & 0.6419 & 0.5628 & 0.0148 \\
\hline Spain & 0.9479 & 0.8942 & 0.8389 & 0.7826 & 0.7242 & 0.6633 & 0.1202 \\
\hline Sweden & 0.9220 & 0.8427 & 0.7654 & 0.6866 & 0.6072 & 0.5283 & 0.0137 \\
\hline United Kingdom & 0.9284 & 0.8551 & 0.7830 & 0.7123 & 0.6394 & 0.5628 & 0.0340 \\
\hline
\end{tabular}

Note: The figures indicate a probability of the $\mathrm{B}>1$ continuous survival in a certain year during the 12 years analyzed periods.

Source: Own calculations based on Comtrade database with WITS (World Trade Integration Solution) software

\section{Conclusions}

This paper contributes new results and knowledge regarding the B indices for agri-food export performances of the EU-27 countries on global markets in the 2001-2011 period that includes the 2004 and 2007 EU enlargements, using panel unit root tests, mobility indices and the Kaplan-Meier survival rates. The B indices differ between the EU-27 countries. On this basis, specific groups of the EU-27 countries have been identified according to the agri-food 
B index levels between the old EU-15 and new EU-12 countries and their patterns in developments over time. The EU enlargements have contributed to some changes in the B indices. The B indices converge, and the mobility at the agri-food product level is relatively low. The survival rates also differ between the EU-27 countries. The EU enlargements have slightly increased the agri-food export competitiveness of the EU-27 countries on global markets, and particularly that of some established EU-15 countries.

The panel unit root tests suggest that the $\mathrm{B}$ indices converge for each of the EU-27 countries. This implies that both the enlarged EU markets and EU policies, and particularly global developments and trade liberalization, have created competitive pressures for agri-food exports on global markets towards harmonizing rules to be respected in order to become or remain competitive.

The degree of mobility in patterns throughout the entire distribution of the B indices for agri-food products is found to be relatively low. This particularly holds true for some EU-15 countries with a greater number of agri-food products with B>1 and over a longer period.

The Kaplan-Meier survival analysis confirmed differences in the survival rates for the mean values of the $\mathrm{B}>1$ indices between the EU-27 countries. The EU-27 countries with the higher median B indices are associated with a longer duration for the agri-food mean values of the $\mathrm{B}>1$ indices. This finding suggests two significant features and two significant implications for agri-food export competitiveness for the EU-27 countries on global agri-food markets. First, the EU-27 countries with a greater number of competitive (mean values of the B>1) agri-food products in global markets are more likely to have a longer duration with a greater survival rate in agri-food export competitiveness. Second, the duration of the agri-food revealed comparative advantages $(B>1)$ measured by the survival rates is higher for some of the old EU-15 countries than for the new EU-12 countries. This more pronounced agri-food export competitiveness duration performance for some of the old EU-15 member countries 
(e.g. the Netherlands, France, and Spain) on global markets is related to a greater number of competitive agri-food products. This can be explained by a longer tradition of agri-food sector competitiveness in complex agri-food international trade marketing and thus by a greater maturity of presence on agri-food markets. This implies the importance of the agri-food sector internationalization and competitive agri-food export integration in global markets in order to assure the importance of greater market efficiency and transmission between national and global agri-food markets.

Finally, the level and patterns in development of the B indices for agri-food products for each of the EU-27 countries in the world markets are mixed. This heterogeneity of products requires further disaggregated analysis for the most prominent agri-food product groups and different market segments in order to improve the quality of the databases, and the related policies aiming at improving their revealed comparative advantages, expansion and duration of competitive agri-food exports. The analysis focusing on the main exporting agri-food products that are competitive in demand on global consumer markets is an issue for future research.

\section{References}

Akman, P. and Kassim, H. (2010) 'Myths and Myth-Making in the European Union: The Institutionalization and Interpretation of EU Competition Policy', JCMS: Journal of Common Market Studies, Vol. 48, No. 1, pp. 111-132.

Balassa, B. (1965) 'Trade Liberalization and Revealed Comparative Advantage', The Manchester School of Economic and Social Studies, Vol. 33, No. 2, pp. 99-123. 
Balassa, B. (1977) 'Revealed Comparative Advantage Revisited: An Analysis of Relative Export Shares of the Industrial Countries, 1953-71', The Manchester School of Economic and Social Studies, Vol. 45, No. 4, pp. 327-344.

Balassa, B. (1971) 'Trade Policies in Developing Countries', The American Economic Review, Vol. 61, No. 2, pp. 178-187.

Balassa, B. (ed.) (1975) European Economic Integration (Amsterdam: North-Holland; New York: Elsevier).

Balassa, B. (1988) 'The Lessons of East Asian Development: An Overview', Economic Development and Cultural Change, Vol. 36, No. 3, pp. S273-S290.

Baltagi, B. (2008) Econometric Analysis of Panel Data (New York: Wiley).

Besedeš, T. and Prusa, T.J. (2006) 'Ins, Outs, and the Duration of Trade', Canadian Journal of Economics, Vol. 39, No. 1, pp. 266-295.

Bojnec, Š. and Fertő, I. (2008) 'European Enlargement and Agro-Food Trade', Canadian Journal of Agricultural Economics, Vol. 56, No. 4, pp. 563-579.

Bojnec, Š. and Fertő, I. (2012) 'Does EU Enlargement Increase Agro-Food Export Duration?', The World Economy, Vol. 35, No. 5, 609-631.

Choi, I. (2001) 'Unit Root Tests for Panel Data', Journal of International Money and Finance, Vol. 20, No. 2, pp. 249-272.

Chow, G.C. (1960) 'Tests of Equality between Sets of Coefficients in Two Linear Regressions', Econometrica, Vol. 28, No. 3, 591-605.

Cleves, M.A., Gould, W.W. and Gutierez, R.G. (2004) An Introduction to Survival Analysis Using STATA (Texas: Stata Press, College Station).

Commission of the European Communities (2011) Study on the Competitiveness of the European Meat Processing Industry (Brussels: Commission of the European Communities). http://ec.europa.eu/enterprise/sectors/food/files/report_compmeat_en.pdf. 
Crespo, N. and Fontoura, M.P. (2007) 'Integration of CEECs into EU Market: Structural Change and Convergence', JCMS: Journal of Common Market Studies, Vol. 45, No. 3, pp. 611-632.

Daugbjerg, C. and Swinbank, A. (2007) 'The Politics of CAP Reform: Trade Negotiations, Institutional Settings and Blame Avoidance', JCMS: Journal of Common Market Studies, Vol. 45, No. 1, pp. 1-22.

Deardorff, A. (1974) 'Factor Proportions and Comparative Advantage in the Long Run: Comment, Journal of Political Economy, Vol. 82, No. 4, 829-833.

De Benedictis, L. and Tamberi, M. (2004) 'Overall Specialization Empirics: Techniques and Applications', Open Economies Review, Vol. 15, No. 4, pp. 323-346.

FAO (2013) FAOSTAT. Rome: Food and Agricultural Organisation of the United Nations. Available at: http://faostat.fao.org/.

Fertő, I. and Hubbard, L.J. (2003) 'Revealed Comparative Advantage and Competitiveness in Hungarian Agri-Food Sectors', The World Economy, Vol. 26, No. 2, pp. 247-259.

Findlay, R. (1970) 'Factor Proportions and Comparative Advantage in the Long Run: Comment', Journal of Political Economy, Vol. 78, No. 1, 27-34.

Findlay, R. (1995) Factor Proportions, Trade and Growth. Cambridge: MIT Press.

Grossman, G. and Helpman, E. (1991) Innovation and Growth in the Global Economy. Cambridge: MIT Press.

Hay, C. (2007) 'Keynote Article: What Doesn’t Kill You Can Only Make You Stronger: The Doha Development Round, the Services Directive and the EU's Conception of Competitiveness', JCMS: Journal of Common Market Studies, Vol. 45, No. s1, pp. 25-43. Howarth, D. (2007) 'Internal Policies: Reinforcing the New Lisbon Message of Competitiveness and Innovation', JCMS: Journal of Common Market Studies, Vol. 45, No. s1, pp. 89-106. 
Im, K., Pesaran, H. and Shin, Y. (2003) 'Testing for Unit Roots in Heterogeneous Panels', Journal of Econometrics, Vol. 115, No. 1, pp. 53-74.

Latruffe, L. (2010) Competitiveness, Productivity and Efficiency in the Agricultural and AgriFood Sectors, OECD Food, Agriculture and Fisheries Papers, No. 30 (Paris: OECD Publishing). http://dx.doi.org/10.1787/5km91nkdt6d6-en.

Liesner, H.H. (1958) 'The European Common Market and British Industry', Economic Journal, Vol. 68, No. 270, pp. 302-316.

Lucas, R. (1988) 'On the Mechanics of Economic Development', Journal of Monetary Economics, Vol. 22, No. 1, 3-22.

Maddala, G.S. and Wu, S. (1999) 'A Comparative Study of Unit Root Tests with Panel Data and A New Simple Test', Oxford Bulletin of Economics and Statistics, Vol. 61, No. S1, pp. 631-652.

Mayes, D.G. (1978) 'The Effects of Economic Integration on Trade', JCMS: Journal of Common Market Studies, Vol. 17, No. 1, pp. 1-25.

Ng, S. and Perron, P. (2001) 'Lag Length Selection and the Construction of Unit Root Tests with Good Size and Power', Econometrica, Vol. 69, No. 6, pp. 1519-1554.

Shorrocks, A. (1978) 'The Measurement of Mobility', Econometrica, Vol. 46, No. 5, pp. $1013-1024$.

Török, Á. and Jámbor, A. (2013) 'Agri-Food Trade of the New Member States since the EU Accession', Agricultural Economics - Czech, Vol. 59, No. 3, pp. 101-112.

United Nations Statistical Division (UNSD). (2013) Commodity Trade Database (COMTRADE), available through World Bank's World Integrated Trade Solution (WITS): www.wits.worldbank.org.

Vollrath, T.L. (1991) 'A Theoretical Evaluation of Alternative Trade Intensity Measures of Revealed Comparative Advantage', Weltwirtschaftliches Archiv, Vol. 130, No. 2, pp. 
263-279.

WTO (2013) International Trade Statistics 2012. Geneva: World Trade Organisation. available at http://www.wto.org/english/res_e/statis_e/its_e.htm.

Young, A. (1991) 'Learning-by-Doing and Dynamic Effects of International Trade', Quarterly Journal of Economics, Vol. 106, No. 2, 396-406.

Zysman, J. and Schwartz, A. (1998) 'Reunifying Europe in an Emerging World Economy: Economic Heterogeneity, New Industrial Options, and Political Choices', JCMS: Journal of Common Market Studies, Vol. 36, No. 3, pp. 405-429. 